\title{
Stress of Five Heavy Metals on the Resistance of Isolates from Swine Wastewater to Four Antibiotics
}

\author{
Yanbin $\mathrm{Xu}^{1,2 *}$, Jingjing Ruan${ }^{2}$, Maoyu Hou${ }^{2}$, Xinxin Zhao ${ }^{2}$, Li Zheng ${ }^{2}$, Shaoqi Zhou ${ }^{1}$ and Baohong Yuan ${ }^{3}$ \\ ${ }^{1}$ College of environmental science and engineering, South China University of Technology, Guangzhou 510008, China \\ ${ }^{2}$ School of environmental science and engineering, Guangdong University of Technology, Guangzhou 510006, China \\ ${ }^{3}$ School of Basic Courses, Guangdong Pharmaceutical University, Guangzhou 510006, China
}

\begin{abstract}
Co-existence of heavy metals and antibiotics becomes increasingly common in environmental pollution. To investigate the stress of heavy metals on microbial resistance to antibiotics, fifty-six strains of bacteria were initially isolated from some swine water in Guangzhou city, based on their resistance to four antibiotics (cefradine, norfloxacin, amoxicillin, tetracycline) and five heavy metals $\left(\mathrm{Pb}^{2+}, \mathrm{Cr}(\mathrm{VI}), \mathrm{Hg}^{2+}, \mathrm{Cu}^{2+}, \mathrm{Zn}^{2+}\right)$, a gram-negative isolate, Pseudomonas putida XX6, was selected to study the detail stress rules of heavy metals on its resistance to antibiotics. The antibiotics incidences of these isolates were in the order of norfloxacin>amoxicillin>cefradine>tetracycline, and that of $P$. putida $\mathrm{XX} 6$ was cefradine>amoxicillin $\approx$ tetracycline>norfloxacin. The addition of heavy metals made all isolates' resistance to antibiotics decrease, and $\mathrm{Cr}(\mathrm{VI})$ impacted their resistance to norfloxacin most obviously. If the concentration of heavy metals was the most important factor affecting the resistance of $P$. putida XX6 to the antibiotics? There was a positive correlation between the bacterial resistances to antibiotics and heavy metals of low concentrations, and the correlation turned to negative with the concentrations of heavy metals increasing. But the bacterial resistance to amoxicillin or cefradine remained irrelevant to the concentrations of $\mathrm{Cr}(\mathrm{VI})$ or $\mathrm{Pb}^{2+}$. Results showed that the combined effect of antibiotics and heavy metals could alter their individual effect on bio-toxicity as well as on the biological removal capability of pollutants.
\end{abstract}

Keywords: Antibiotic; Heavy metal; Resistance; Stress; Susceptibility

\section{Introduction}

The large-scale application of veterinary antibiotics in livestock industry makes swine wastewater a major source of antibiotics pollution [1]. And abuse of antibiotics (overuse or misuse) has been shown to be a major factor in emergence of bacterial resistance to antimicrobials [2]. Genetic diversity and neutral or silent changes within genes are responsible for drug resistance [3] and microbes can acquire drug resistance by gene mutation or horizontal gene transformation, which makes diseases more difficult and expensive to be diagnosed and treated [4]. Furthermore, increase of drug resistant microbes in ecosystem may lead to worldwide public health issues. The mineral feed and the corrosion of metallic installations could be major sources of heavy metals in swine wastewater [5]. Bacteria could develop stable resistance to heavy metals after long term exposure at low levels [6].

The environment complex-polluted by heavy metals and antibiotics may lead to the enrichment of resistant bacteria [7-10] through collaborative- or cross-resistance to heavy metals or co-regulation of resistance pathways [11]. Some mechanisms of heavy metal tolerance might be linked to the antimicrobial resistance mechanisms and even affect the bacterial resistance to antibiotics. Therefore, co-existence of antibiotics and heavy metals may cause a more serious environmental problem due to the stress of heavy metals on the microbial resistance to antibiotics.

Heavy metal contaminants are used for selective proliferation of antibiotic resistance based on the co-selection mechanism [12]. And there were still few reports about the impacts of heavy metals on the bacterial antibiotic resistance, and the detail effect of heavy metal types and concentrations on bacterial resistance to antibiotics were significant and worth researching. In the present paper, the isolates from swine wastewater are investigated on their resistances to some antibiotics and heavy metals, and the study on one of the isolates aim to reveal the stress of heavy metals on the bacterial resistance to antibiotics. Results will draw great attention to the risk of complex pollution of heavy metals and antibiotics, and give guide for the bioremediation techniques of the contaminated sites by heavy metals and antibiotics.

\section{Materials and Methods}

\section{Materials}

The resistant strains were isolated from some swine wastewater of a livestock husbandry in Guangzhou, China.

The stock solutions of $100 \mathrm{mg} / \mathrm{mL}$ of $\mathrm{Pb}^{2+}, \mathrm{Cr}(\mathrm{VI}), \mathrm{Hg}^{2+}, \mathrm{Cu}^{2+}$ and $\mathrm{Zn}^{2+}$ were prepared by dissolving $\mathrm{Pb}\left(\mathrm{NO}_{3}\right)_{2}, \mathrm{~K}_{2} \mathrm{Cr}_{2} \mathrm{O}_{7}, \mathrm{CuSO}_{4} \cdot 5 \mathrm{H}_{2} \mathrm{O}$, $\mathrm{ZnSO}_{4} \cdot 7 \mathrm{H}_{2} \mathrm{O}$ in the deionized water and $\mathrm{HgSO}_{4}$ in $10 \% \mathrm{H}_{2} \mathrm{SO}_{4}$ solution. The stock solutions were stored at $4^{\circ} \mathrm{C}$ and added in the basic medium to study the bacterial resistance to heavy metals.

The stock solutions containing $640 \mu \mathrm{g} / \mathrm{mL}$ of tetracycline, amoxicillin, norfloxacin and cefradine were prepared by dissolving amoxicillin or cefradine or tetracycline powder in the PSB buffer, norfloxacin powder in $1 \mathrm{~mol} / \mathrm{L} \mathrm{NaOH}$ solution. These solutions were also stored at $4^{\circ} \mathrm{C}$ no more than $12 \mathrm{~h}$. The isolates were inoculated on the Mueller-Hinton agar (Oxoid) medium containing a certain volume of the stock solutions to study their resistance.

Four kinds of antimicrobial discs: Tetracycline $(30 \mu \mathrm{g})$, amoxicillin

*Corresponding author: Yanbin $\mathrm{Xu}$, Department of environmental science and engineering, South China University of Technology, Guangzhou 510008, China, Tel: +8613660621925; E-mail: hopeybxu@163.com

Received May 31, 2014; Accepted June 19, 2014; Published June 30, 2014

Citation: Xu YB, Ruan JJ, Hou MY, Zhao XX, Zheng L, et al. (2014) Stress of Five Heavy Metals on the Resistance of Isolates from Swine Wastewater to Four Antibiotics. Hydrol Current Res 5: 173. doi:10.4172/2157-7587.1000173

Copyright: (c) $2014 \mathrm{Xu}$ YB, et al. This is an open-access article distributed under the terms of the Creative Commons Attribution License, which permits unrestricted use, distribution, and reproduction in any medium, provided the original author and source are credited. 
$(20 \mu \mathrm{g})$, norfloxacin $(10 \mu \mathrm{g})$, and cefradine $(30 \mu \mathrm{g})$ used in the present paper were bought from Hangzhou Tianhe Microorganism Reagent Co. Ltd.

The basic medium was prepared by dissolving $3 \mathrm{~g}$ of beef extract, 10 $\mathrm{g}$ of peptone, $5 \mathrm{~g}$ of sodium chloride and $20 \mathrm{~g}$ of agar in $1 \mathrm{~L}$ deionized water, and the terminal $\mathrm{pH}$ ranged from 7.0 to 7.2.

The density of the bacterial suspension used in this research was about $10^{8} \mathrm{cfu} / \mathrm{mL}$.

\section{Methods}

Isolation of the strains: Antibiotics resistant strains were obtained by the method of ten-fold serial dilution and screened by inoculating onto Mueller-Hinton agar media added with $1.0 \mu \mathrm{g} / \mathrm{mL}$ of antibiotics (tetracycline or amoxicillin or norfloxacin or cefradine) and heavy metals $\left(10 \mu \mathrm{g} / \mathrm{mL}\right.$ of $\mathrm{Pb}^{2+}$ or $\mathrm{Cr}(\mathrm{VI})$ or $\mathrm{Hg}^{2+}$ or $\mathrm{Cu}^{2+}$ or $\left.\mathrm{Zn}^{2+}\right)$. After an incubation of $24 \mathrm{~h}$ at $37^{\circ} \mathrm{C}$, morphological observations were recorded and biochemical tests were done on bacterial isolates.

Determination of the tolerance to heavy metals and antibiotics: Five stock solutions containing $\mathrm{Pb}^{2+}, \mathrm{Cr}(\mathrm{VI}), \mathrm{Hg}^{2+}, \mathrm{Cu}^{2+}$ and $\mathrm{Zn}^{2+}$ were added into the basic medium and the final concentrations of each heavy metal were modulated in the range of 0 to $15 \mathrm{mg} / \mathrm{mL}$, and the final concentrations of each antibiotic were modulated in the range of 0 to $10 \mu \mathrm{g} / \mathrm{mL}$. $0.1 \mathrm{ml}$ of bacterial suspension was spread onto the basic medium with heavy metal and incubated at $37^{\circ} \mathrm{C}$ for $24 \mathrm{~h}$. The Minimum Inhibitory Concentrations (MICs) with these five heavy metals and these four antibiotics were determined by the agar dilution method, and the control strain was Escherichia coli K-12. The concentration range of heavy metals for the following cross-resistance experiments was determined based on the MICs.

Cross-resistance experiments: The bacterial cross-resistances to heavy metals and antibiotics were determined by a modified KirbyBauer disk diffusion method. The bacterial susceptibility to these four antibiotics was assessed by the disk diffusion method, according to the guidelines from the National Committee for Clinical Laboratory Standards (NCCLS), using sensi-disks (Becton-Dickinson) on Mueller-Hinton agar (Oxoid) plates. Based on the results of MIC tests, different volume of the stock solutions were added into the sterilized Mueller-Hinton agar medium at $60^{\circ} \mathrm{C}$ to get the testing medium containing heavy metal and the terminal concentration of the heavy metal in these plates were $0,0.01,0.2,1,5,10,15 \mathrm{mg} / \mathrm{mL}$, respectively. $0.1 \mathrm{~mL}$ bacterial suspension was spread on the media and then three pieces of same antibiotic disc were placed onto the plates. After a culture period of $24 \mathrm{~h}$ at $37^{\circ} \mathrm{C}$, the influences of heavy metals types and concentrations on the bacterial antibiotic resistance were concluded according to the inhibition zone diameters and the bacterial growth.

Statistical analysis: Statistical evaluation of the data was conducted using SPSS Version 17.0 (SPSS), where any statistical probability equal to or less than 0.05 was considered as significant.

\section{Results}

\section{The dominant strains and their resistance}

A total of 56 antibiotic resistant bacteria were isolated from the swine wastewater, and the ratio between gram positive bacteria and gram negative bacteria was $3: 4$. The incidence of antibiotic resistance bacteria was shown in Figure 1. The bacterial resistance to these antibiotics from strong to weak was in the order as: norflaxacin, amoxicillin, cefradine and tetracycline, which was consistent with the antibacterial spectrum of each antibiotic and the bacterial characteristics.
The incidences of the cross-resistant bacteria to antibiotic and heavy metal were shown in Figure 2. Based on Figure 1 and Figure 2, it could be noted that the number of strains with resistance to both antibiotic and heavy metal decreased by $8.93 \%-71.42 \%$ with the addition of heavy metals. More than $50 \%$ isolates could resist to the combination of amoxicillin and $\mathrm{Zn}^{2+}$ or $\mathrm{Cu}^{2+}$, norfloxacin and $\mathrm{Hg}^{2+}$, tetracycline and $\mathrm{Zn}^{2+}$ or $\mathrm{Cu}^{2+}$. The addition of $\mathrm{Cr}(\mathrm{VI})$ decreased the incidence of norfloxacin resistant strains from $85.71 \%$ to $14.29 \%$. The bacterial resistance to cefradine was significantly inhibited by the addition of $\mathrm{Pb}^{2+}$ and $\mathrm{Cr}(\mathrm{VI})$, which could be due to the high toxicity of some heavy metals or the increased inhibitory effects from the combination of heavy metals and antibiotics.

\section{The testing strain and its MICs}

Since the bacterial resistance varied with strain and its growth status, to study the bacterial resistance to antibiotic and heavy metal simultaneously, one of the 56 strains, identified as Pseudomonas putida XX6, was focused on in the present paper due to its strong resistance to antibiotics and heavy metals.

The MICs of $\mathrm{Pb}^{2+}, \mathrm{Cu}^{2+}, \mathrm{Zn}^{2+}$ and $\mathrm{Cr}(\mathrm{VI})$ were $10 \mathrm{mg} / \mathrm{mL}$, while that of $\mathrm{Hg}^{2+}$ was $5 \mathrm{mg} / \mathrm{mL}$; MICs of the antibiotics were $5 \mu \mathrm{g} / \mathrm{mL}$ for amoxicillin, $4 \mu \mathrm{g} / \mathrm{mL}$ for norfloxacin, $6.25 \mu \mathrm{g} / \mathrm{mL}$ for cefradine and 5

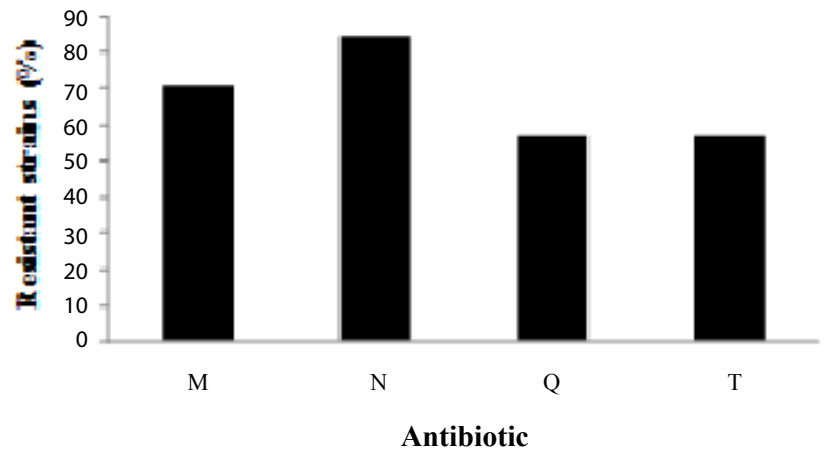

Figure 1: Incidence of the antibiotic resistant bacteria from the swine wastewater in the livestock husbandry $(n=56)$ *Abbreviations for resistance to specific antibiotics are as follow: M-amoxicillin, Q-cefradine, N-norfloxacin, T-tetracycline.

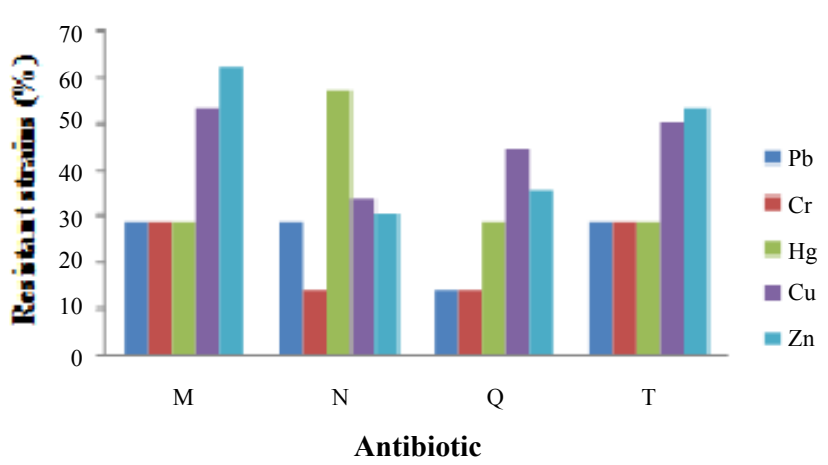

"Abbreviations for resistance to specific antibiotics are as follow: M-amoxicillin Q-cefradine, N-norfloxacin, T-tetracycline.

Figure 2: Incidences of the cross-resistant bacteria to antibiotic and heavy metal. The concentrations of heavy metals and antibiotics in the media were $10 \mathrm{mg} / \mathrm{L}$ of $\mathrm{Pb}^{2+}$ or $\mathrm{Cr}(\mathrm{VI})$ or $\mathrm{Hg}^{2+}$ or $\mathrm{Cu}^{2+}$ or $\mathrm{Zn}^{2+}$ and $1.0 \mathrm{mg} / \mathrm{L}$ of tetracycline or amoxicillin or norfloxacin or cefradine, respectively. 
$\mu \mathrm{g} / \mathrm{mL}$ for tetracycline. And the resistance to these four antibiotics was in the order of cefradine $>$ amoxicillin $\approx$ tetracycline $>$ norfloxacin.

\section{The results of the bacterial resistance}

Based on the results of the bacterial MICs and the analysis results of the Between-Subjects Effects by the SPSS software as shown in Table 1, it was concluded that both individual and combined effect of heavy metals and antibiotics on the bacterial antibiotic resistance were significant $(\mathrm{P}<0.05)$.

The analysis results of the Between-Subjects Effects showed that the single heavy metal, single antibiotic or the interaction between single heavy metal and single antibiotic could affect the strain significantly. However, the results of One-Way Analysis of Variance (ANOVA) illustrated that the bacterial resistance to antibiotics varied with both the types and concentrations of heavy metals. And the heavy metal concentration was the most significant impact factor on bacterial antibiotic resistance in statistical analysis $(\mathrm{F}>\lambda 0.01$ and $\mathrm{P}<0.05)$.

The variation of the antibiotic inhibitory zone diameter with the concentration of heavy metal was shown as Figure 3 . The bacterial resistance of $P$. putida XX6 to the four antibiotics was in the order of amoxicillin $>$ cefradine $>$ tetracycline $>$ norfloxacin, which was different from the resistance of the total 56 isolates shown in Figure 1. The influence of the five heavy metals on tetracycline was similar to that on amoxicillin and the bacterial resistance to tetracycline and amoxicillin could be improved by the heavy metals of lower concentration, whereas its antibiotic resistance decreased with the heavy metal concentrations increasing. However, the higher the concentrations of the heavy metals co-existed with tetracycline, the stronger the bacteriostasis was, as compared to amoxicillin. With the heavy metals concentration increasing, the bacterial resistance to $\mathrm{Cr}(\mathrm{VI})$ or $\mathrm{Hg}^{2+}$ or $\mathrm{Pb}^{2+}$ or $\mathrm{Zn}^{2+}$ with cefradine and $\mathrm{Zn}^{2+}$ or $\mathrm{Cu}^{2+}$ with norfloxacin decreased until the bacterium was inhibited. There was no significant correlation between the bacterial resistance to amoxicillin or cefradine and $\mathrm{Cr}(\mathrm{VI})$ or $\mathrm{Pb}^{2+}$ of different concentrations. Among these five heavy metals, the influences of $\mathrm{Hg}^{2+}$ and $\mathrm{Zn}^{2+}$ on the antibiotic resistance of Pseudomonas putida XX6 were the most significant, as the addition of $\mathrm{Hg}^{2+}$ made the bacterial resistance to norfloxacin decrease rapidly, and the inoculant failed to grow up on the media with $0.01 \mathrm{mg} / \mathrm{mL} \mathrm{Hg}^{2+}$ and the norfloxacin disc. On the other hand, the growth of P. putida XX6 could be observed on the media with $10 \mathrm{mg} / \mathrm{mL} \mathrm{Hg}^{2+}$ and the tetracycline disc or cefradine disc, which might be relative to the decreasing in the biological toxicity due to the reaction between some heavy metal and antibiotic, or could be due to the fact that the bacterial tolerance to $\mathrm{Hg}^{2+}$ might be induced by tetracycline or cefradine. With the concentration of $\mathrm{Zn}^{2+}$ increasing, the bacterial resistance to all antibiotics strengthened first and then weakened, and combined effect showed co-resistance first and then costerilization.

\section{Discussion}

The pollution of heavy metals from industrial and mining activities attracts extensive attention worldwide and intense arguments on its persistence and bio-toxicity. Abuse of antibiotics in livestock husbandry to prevent and cure diseases has resulted in significant amount of antibiotics being exported into the natural environment, which eventually becomes a potential threat to the public health. Co-existence of heavy metals and antibiotics has become a universal phenomenon in the polluted and natural environment. In the present paper, among the 56 isolates from the swine wastewater, the ratio of gram negative to gram positive bacteria was about $4: 3$, which was almost similar to the clinical data of isolates. In the last few decades, continuous studies were conducted on resistant microorganisms and there was a wide variety of sites where lived the antibiotic resistant microorganisms [8,13-16] .

By statistical analysis on the strain numbers resistant to each antibiotic, the general resistance of the isolates from some swine wastewater to these four antibiotics was in the order of norfloxacin> amoxicillin $>$ cefradine $>$ tetracycline. While Matyar et al. [11] studied the resistance of 236 Gram-negative bacteria isolates (from seawater, sediment and shrimps in the industrially polluted Iskenderun Bay) to 16 different antibiotics and 5 heavy metals and found the incidence of resistance to ampicillin was the biggest, while that of cefepime was the least. Vaseeharan et al. [17] also found that the isolates from shrimp culture hatcheries and ponds in India showed high degree of resistance to ampicillin and there also was a tendency towards a high frequency of ampicillin resistance among all the heavy metals resistant isolates. So the habitat and the microbial population were the main effect factors on the resistant characteristics. The addition of $\mathrm{Cr}$ (VI) reduced the incidence of norfloxacin resistance strains from $85.71 \%$ to $14.29 \%$. More than $50 \%$ of these isolates could resist to amoxicillin and $\mathrm{Zn}^{2+}$ or $\mathrm{Cu}^{2+}$, norfloxacin and $\mathrm{Hg}^{2+}$, tetracycline and $\mathrm{Zn}^{2+}$ or $\mathrm{Cu}^{2+}$ simultaneously, while the bacterial resistance to cefradine decreased significantly with the concentration of $\mathrm{Pb}^{2+}$ and $\mathrm{Cr}$ (VI) increasing, which could be explained as the lowered or heightened toxicity of the co-existence of heavy metals and antibiotics. Akiyama and Savin [18] also found that the antibiotics resistance levels in surface water could be affected by other pollutants including heavy metal in effluent, but the detailed mechanisms remained unclear and there were few studies focusing on the incidence of antibiotic and heavy metal resistance in bacteria.

Since the antibiotic resistance of gram-negative bacteria has got more attention than the gram-positive bacteria, especially in hospital settings [19], to reveal the detailed relationship between antibiotics resistance and heavy metals resistance, a gram-negative bacterium, Pseudomonas putida XX6, was selected and studied. There was a positive correlation between the bacterial resistance to antibiotics and heavy metals of lower concentrations, while the correlation

\begin{tabular}{|c|c|c|c|c|c|}
\hline Source & Type III Sum of Squares & df & Mean Square & $\mathbf{F}$ & Sig. \\
\hline Corrected Model & $10701.109 a$ & 14 & 764.365 & 8.351 & 0 \\
\hline Intercept & 114427 & 1 & 114427 & 1250.16 & 0 \\
\hline Heavy metals & 4990.87 & 3 & 1663.62 & 18.176 & 0 \\
\hline Antibiotics & 3039.51 & 3 & 1013.17 & 11.069 & 0 \\
\hline Heavy Metals * Antibiotics & 2143.01 & 8 & 267.876 & 2.927 & 0.004 \\
\hline Error & 23340.1 & 255 & 91.53 & & \\
\hline Total & 154560 & 270 & & & \\
\hline Corrected Total & 34041.2 & 269 & & & \\
\hline
\end{tabular}

$\mathrm{R}$ Squared $=.314($ Adjusted $\mathrm{R}$ Squared $=.277)$ 


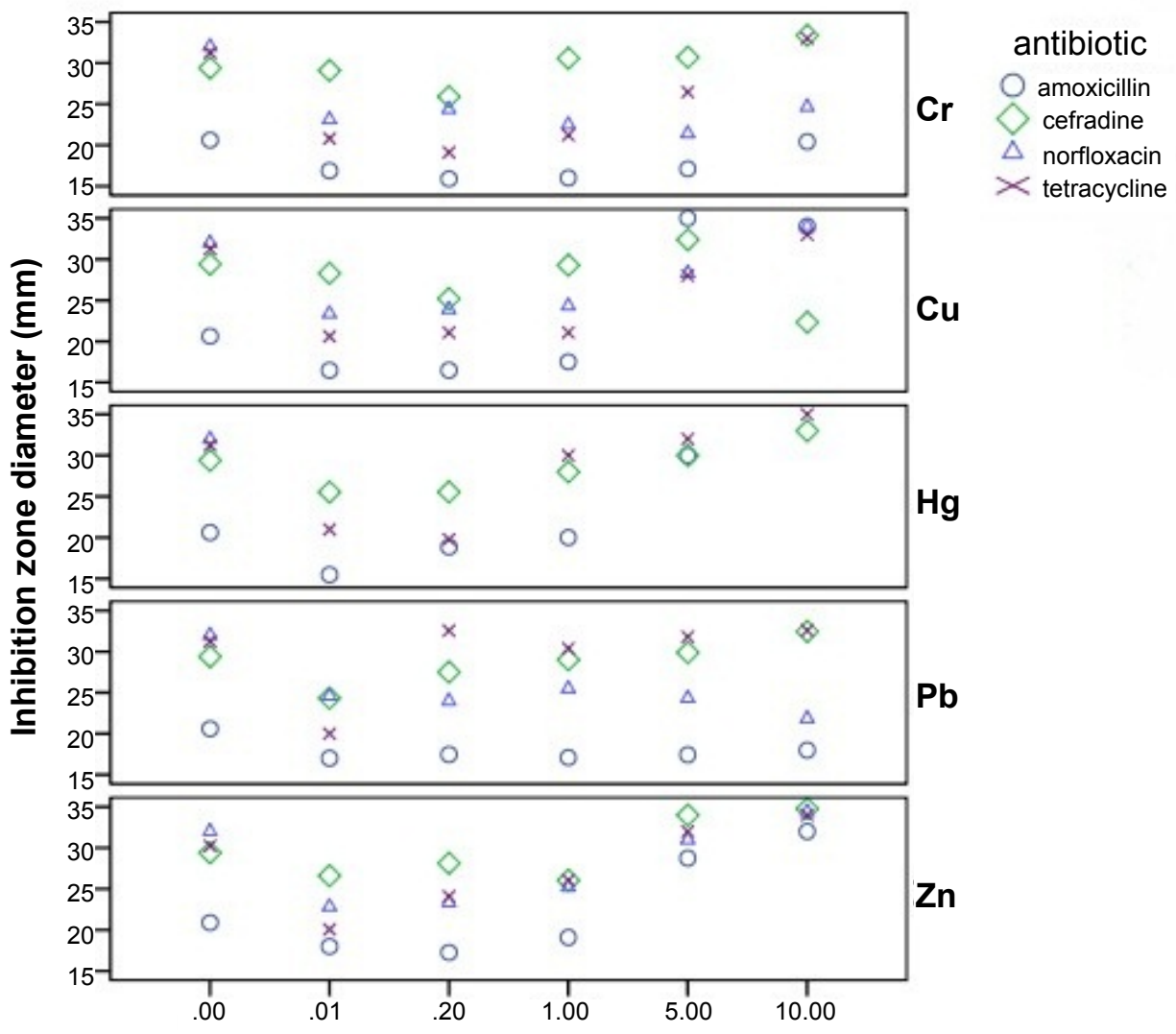

Heavy metal concentration $(\mathrm{mg} / \mathrm{mL})$

Figure 3: Variation of the antibiotics inhibition zone diameter with the types and concentrations of heavy metals. It illustrated that the bacterial resistance to these four antibiotics was in the order of amoxicillin>cefradine>tetracycline>norfloxacin. The heavy metal of lower concentrations could strengthen the bacterial resistance to most antibiotics. But the bacterial resistance to amoxicillin and cefradine could not be affected obviously by $\mathrm{Cr}(\mathrm{VI})$ or $\mathrm{Pb} \mathrm{b}^{2+}$ of different concentrations.

turned to negative with the concentration of heavy metals increasing, which applied to most combinations of antibiotics and heavy metals. And there were still few combinations that showed no significant relationship between the bacterial resistance to the antibiotics and the concentrations of the heavy metals, such as amoxicillin or cefradine and $\mathrm{Cr}(\mathrm{VI})$ or $\mathrm{Pb}^{2+}$ of different concentrations. It had been proved that although some heavy metals of trace level is mandatory for the bacterial growth, overloaded heavy metals could affect the growth of bacteria by restraining the activity of protein or enzyme [20]. In addition, mercury had been proved more toxic than cobalt, zinc and lead in terms of weight [21]. Abskharon et al. [22] also found that total protein content of E.coli ASU3 decreased and the induction of antioxidant enzymes such as catalase, peroxidase and ascorbate peroxidase increased with the copper concentration increasing, and the bacterial toxicity order was $\mathrm{Cr}(\mathrm{VI})>\mathrm{Cu}^{2+}>\mathrm{Co}^{2+}>\mathrm{Pb}^{2+}>\mathrm{Ni}^{2+}>\mathrm{Cr}^{3+}>\mathrm{Cd}^{2+}>\mathrm{Zn}^{2+}$. And the resistance of Pseudomonas putida XX6 to the four antibiotics and five heavy metals might be synergistic or antagonistic, which depended on the type and concentration of the co-existed heavy metal.

The biological resistance mechanism towards heavy metal or antibiotics has been studied for several decades. Based on the complete genome sequencing of Cupriavidus sp. strain BIS7 and BLAST, a number of proteins involved in heavy-metal resistance had been identified, such as $\mathrm{CzcE}$ [involved in $\mathrm{Cd}(\mathrm{II}), \mathrm{Zn}(\mathrm{II})$, and $\mathrm{Co}(\mathrm{III})$ resistance] and $\mathrm{Znt} \mathrm{A}$ [P-type ATPase involved in $\mathrm{Zn}(\mathrm{II}), \mathrm{Cd}(\mathrm{II}), \mathrm{Tl}(\mathrm{I})$, and $\mathrm{Pb}(\mathrm{II})$ resistance] [23]. Though the bacterial resistance to heavy metals is considered to be similar to that of antibiotics, and the resistant genes are always located in some mobile elements such as plasmid, there are still lack of detailed explanations on the mechanism of cross resistance to heavy metals and antibiotics. Both contaminants could activate some antioxidant enzymes such as superoxide dismutase (SOD), peroxidase (POD) and catalase (CAT), which are helpful to overcome oxidative stress and help bacteria to survive under pressure [24,25]. Apart from inducing proteins, efflux pumps might also be responsible for the crossresistance between heavy metals and antibiotics [26], which explains why the antibiotic resistance can be strengthened by some heavy metals of certain concentrations. Other reasons for collaborative resistance might result from some unknown chemical reactions between heavy metals and antibiotics or the decomposed product of antibiotics; heavy metals might modify the target site of action to induce its affinity with antibiotics. As complexion of heavy metals and antibiotics occurred, the overall combination had decreased toxicity to bacteria, giving rise to co-resistance. According to Zhang et al. [27], when heavy metal and antibiotic reacted to form a by-product of lower toxicity, bacterial resistance would appear stronger; however, the higher the toxicity of the by-product was, the weaker the bacterial resistance was. The degree of complexion varied with the heavy metals concentration, which might be due to the microbial cross-resistance to heavy metals and antibiotics. Some heavy metals at lower concentrations could cause dysfunction in some proteins such as some metallothionein-like protein, which did not enhance resistance but instead, it caused resistance losing. It 
Citation: Xu YB, Ruan JJ, Hou MY, Zhao XX, Zheng L, et al. (2014) Stress of Five Heavy Metals on the Resistance of Isolates from Swine Wastewater to Four Antibiotics. Hydrol Current Res 5: 173. doi:10.4172/2157-7587.1000173

Page 5 of 5

was deduced that the heavy metals might damage enzyme by toxic reaction with antibiotics. The production of the reactive oxygen species (ROS) enhanced with the heavy metals concentration increasing, the balance between ROS and the antioxidant enzymes was broken and the excess ROS was likely to reduce the effect of toxicity by oxidation of antibiotics or their derivatives [25]. In conclusion, all the chemical reaction, genetic expression, induced enzyme and change of pathway would strengthen or weaken the resistance to the heavy metals and antibiotics. Co-existence of heavy metal and antibiotic could change the bacterial resistance and even might increase the environmental risk, which based on the type and concentration of the stress factors.

\section{Conclusion}

A total of 56 bacterial strains were isolated from some swine wastewater, and the incidence of these 56 bacteria's resistance to antibiotics was in the order of norfloxacin $>$ amoxicillin $>$ cefradine $>$ tet racycline, The number of resistant strains to both antibiotic and heavy metal decreased by $8.93 \%-71.42 \%$ due to the addition of heavy metals. $\mathrm{Cr}$ (VI) affected the bacterial resistance to norfloxacin most obviously. Pseudomonas putida XX6, one of the isolates, could resist the four antibiotics in the descending order was cefradine $>$ amoxicillin $\approx$ tetracycline $>$ norfloxacin. The heavy metal concentration is a dominant factor impacting on the stains' resistance to antibiotics. There was a positive correlation between the bacterial resistance to antibiotics and lower concentrations of heavy metals (no more than $0.01 \mathrm{mg} / \mathrm{mL}$ of $\mathrm{Pb}^{2+}$ or $\mathrm{Cu}^{2+}$ or $\mathrm{Zn}^{2+}, 0.2 \mathrm{mg} / \mathrm{mL}$ of $\mathrm{Cr}(\mathrm{VI})$ or $\mathrm{Hg}^{2+}$ ), while the correlation turned to negative with the concentration of heavy metals increasing, which applied to most combinations of antibiotics and heavy metals. It can be concluded that bioremediation and public health risk of antibiotics would be affected by the heavy metals.

\section{Acknowledgement}

Project (No. 40801194) supported by a Grant from Nature Science fund of China: Project (No. 20100470921) supported by a Grant from China postdoctoral science foundation; Project (No. 0500823) supported by a Grant from Nature Science fund of Guangdong Province, China; Project (No. 2013A3FC0243) supported by a Grant from the Science and Technology Plan of Zhongshan.

\section{References}

1. Ben W, Qiang Z, Pan X, Chen MX (2009) Removal of veterinary antibiotics from Sequencing Batch Reactor (SBR) pretreated swine wastewater by Fenton's reagent. Water Res 43: 4392-4402.

2. Capita R, Carlos AC (2013) Antibiotic-resistant bacteria: a challenge for the food industry. Crit Rev Food Sci 53: 11-48.

3. Köser CU, Feuerriegel S, Summers DK, Archer JAC, Niemann S (2012) Importance of the Genetic Diversity within the Mycobacterium tuberculosis Complex for the Development of Novel Antibiotics and Diagnostic Tests of Drug Resistance. Antimicrob Agents Chemother 56: 6080-6087.

4. Alanis AJ (2005) Resistance to Antibiotics: Are we in the post-antibiotic era? Arch Med Res 36: 697-705

5. Holzel CS, Muller C, Harms KS, Mikolajewski S, Schafer S, et al. (2012) Heavy metals in liquid pig manure in light of bacterial antimicrobial resistance. Environ Res 113: 21-27.

6. Yoshida N, Murooka Y, Ogawa K (1998) Heavy metal particle resistance in Thiobacillus intermedius 13-1 isolated from corroded concrete. J Ferment Bioeng 85: 630-633.

7. Deredjian A, Colinon C, Brothier E, Favre-Bonté S, Cournoyer B et al. (2011) Antibiotic and metal resistance among hospital and outdoor strains of Pseudomonas aeruginosa. Res Microbiol 162: 689-700.
8. Uĝur A, Ceylan Ö (2003) Occurrence of resistance to antibiotics, metals, and plasmids in clinical strains of Staphylococcus spp. Arch Med Res 34: 130-136.

9. Najiah M, Lee SW, Wendy W, Tee LW, Nadirah M et al. (2009) Antibiotic resistance and heavy metals tolerance in gram-negative bacteria from diseased American bullfrog (Rana catesbeiana) cultured in Malaysia. Agr Sci China 8 : 1270-1275.

10. Matyar F, Akkan T, Uçak Y, Eraslan B (2010) Aeromonas and Pseudomonas: antibiotic and heavy metal resistance species from Iskenderun Bay, Turkey (northeast Mediterranean Sea). Environ Monit Assess 167: 309-320.

11. Matyar F, Kaya A, Dinçer S (2008) Antibacterial agents and heavy meta resistance in Gram-negative bacteria isolated from seawater, shrimp and sediment in Iskenderun Bay,Turkey. Sci Total Environ 407: 279-285.

12. Baker-Austin C, Wright MS, Ramunas S, McArthur JV (2006) Co-selection of antibiotic and metal resistance. Trends Microbiol 14: 176-182.

13. Miranda CD, Castillo G (1998) Resistance to antibiotic and heavy metals of motile Aeromonads from Chilean freshwater. Sci Total Environ 224: 167-176.

14. Akinbowale OL, Peng HH, Grant P, Barton MD (2007) Antibiotic and heavy metal resistance in motile Aeromonads and Pseudomonads from rainbow trout (Oncorhynchus mykiss) farms in Australia Int J Antimicrob Ag 30: 177-182.

15. Lee SW, Najiah M, Wendy W, Zahrol A, Nadirah M (2009) Multiple antibiotic resistance and heavy metal resistance profile of bacteria isolated from gian freshwater prawn (Macrobrachium rosenbergii ) hatchery. Agr Sci China 8: 740-745.

16. Pathak SP, Gopal K (2005) Occurrence of antibiotic and metal resistance in bacteria from organs of river fish. Environ Res 98: 100-103.

17. Vaseeharan B, Ramasamy P, Murugan T, Chen JC (2005) In vitro susceptibility of antibiotics against Vibrio spp. and Aeromonas spp. isolated from Penaeus monodon hatcheries and ponds. Int J Antimicrob Ag 26: 285-291.

18. Akiyama T, Savin MC (2010) Populations of antibiotic-resistant coliform bacteria change rapidly in a wastewater effluent dominated stream. Sci Total Environ 408: 6192-6201.

19. Abbas ZG, Lutale JK, llondo MM, Archibald LK (2012) The utility of Gram stains and culture in the management of limb ulcers in persons with diabetes. Int Wound J 9: 677-682.

20. Sharma S, Sundaram CS, Luthra PM, Singh Y, Sirdeshmukh R et al. (2006) Role of proteins in resistance mechanism of Pseudomonas fluorescens against heavy metal induced stress with proteomics approach. J Biotechnol 126: 374 382.

21. Carter JW, Cameron IL (1973) Toxicity bioassay of heavy metals in water using Tetrahymena pyriformis. Water Res 7: 951-961.

22. Abskharon RNN, Hassan SHA, Kabir MH, Qadir SA, El-Rab (2010) The role of antioxidants enzymes of E.coli ASU3, a tolerant strain to heavy metals toxicity in combating oxidative stress of copper. World J Microb Biot 26: 241-247.

23. Hong KW, Thinagaran D, Gan HM, Yin WF, Chan KG (2012) Whole-genome sequence of Cupriavidus sp. strain BIS7, a heavy-metal-resistant bacterium. J Bacteriol 194: 6324.

24. Liu Y, Guan YT, Gao BY, Yue QY (2012) Antioxidant responses and degradation of two antibiotic contaminants. Ecotoxicol Environ Safe 86: 23-30.

25. Weihe E, Kriews M, Abele D (2010) Differences in heavy metal concentrations and in the response of the antioxidant system to hypoxia and air exposure in the Antarctic limpet Nacella concinna. Mar Environ Res 69: 127-135.

26. Fernandes P, Ferreira BS, Cabral JMS (2003) Solvent tolerance in bacteria role of efflux pumps and cross-resistance with antibiotics. Int J Antimicrob Ag 22: 211-216.

27. Zhang Y, Cai XY, Lang XM, Qiao XL, Li XH et al.(2012) Insights into aquatic toxicities of the antibiotics oxytetracycline and ciprofloxacin in the presence of metal: Complexation versus mixture. Environ Pollution 166: 48-56. 